\title{
A MATTER OF OVERRIDING INTEREST: UNREGISTERED EASEMENTS UNDER ALBERTA'S LAND TITLES SYSTEM
}

\author{
BRUCE H. ZIFF*
}

\begin{abstract}
While the Torrens system is designed to reflect the principle of indefeasibility of title, there are overriding interests which will bind subsequent purchasers even absent registration. In the case of Petro-Canada v. Shaganappi Village Shopping Centre, the Alberta Court of Appeal held that an express agreement for a private easement is not an overriding interest. The author comments on the decision and concludes that it leaves room for easements implied by grant or reservation to remain as overriding interests.
\end{abstract}

Si le système Torrens est conçu pour refléter le principe d'irrévocabilité d'un titre, il subsiste toutefois des intérêts qui lient les acquéreurs subséquents même en l'absence d'acte établissant la servitude. Dans la cause Petro Canada $c$. Shaganappi Village Shopping Centre, la Cour d'appel de l'Alberta a conclu qu' une entente expresse de service foncier privé ne constitue pas un droit non soumis à immarriculation. L'auteur commente la décision et conclut qu'elle permet toujours aux servitudes foncières qui découlent d' une concession ou réservation d'appartenir aux droits non soumis d immatriculation.

\section{TABLE OF CONTENTS}

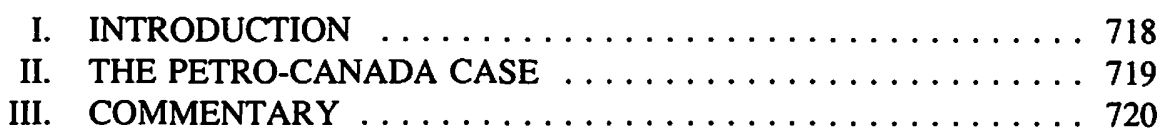

\section{INTRODUCTION}

The Torrens system of land registration, adopted in the Northwest Territories in 1886,' is designed to create a government register of all (or nearly all) interests which affect a given parcel of land. The driving mission is straightforward: there should be no invisible clouds on title. In theory, a purchaser of land should be confident that the title issued by the Registrar of the Land Titles office is indefeasible, at least to the extent that it cannot be undermined by the later discovery of some hidden and prior unregistered interest. Those seeking to preserve an entitlement are therefore motivated to register.

This was the paradigm to which Robert Torrens aspired, but in no jurisdiction in which his system has been adopted has the logic been followed relentlessly. The original Torrens statute was peppered with amendments almost immediately after its enactment and these introduced the first real exceptions. Nowadays some invisible clouds are allowed to loom over title as 'overriding interests', existing outside of the land titles system in all jurisdictions which have adopted the Torrens model, and those interests will bind subsequent purchasers even absent registration. Public easements are accorded this status in Alberta, for instance, as are liens for property taxes. Private easements "granted or acquired under any Act or law in force in Alberta" are also treated as overriding

- Associate Dean, University of Alberta. I am indebted to Kerry Rittich for reviewing the penultimate version of this note.

1. The Territories Real Property Act, S.C. 1886, c. 26. See generally I.L. Head, "The Torrens System in Alberta: A Dream in Operation" (1957), 35 Can. Bar Rev. 1. 
interests. ${ }^{2}$ This last provision is doubly enigmatic: both the rationale of protecting private easements and the proper ambit of that protection have proven elusive. In Petro-Canada Inc. v. Shaganappi Village Shopping Centre Ltd., ${ }^{3}$ the Alberta Court of Appeal addressed these concerns, holding that an agreement for an easement does not constitute an overriding interest within the meaning of the phrase quoted above. The judgment is as terse as the ruling is profound. The purpose of this note will be to develop the analysis and reflect on the implications of the holding.

\section{THE PETRO-CANADA CASE}

Shaganappi acquired title to a shopping centre complex which was putatively the servient tenement of an easement; Petrocan owned the putative dominant tenement, on which a service station was being operated. The easement provided for a right of way over the shopping centre parking area, and was contained in an easement agreement entered into in 1972 between the predecessors in title of the two litigants. No memorandum of title or caveat of the easement was on the title of the servient land when Shaganappi acquired title; it claimed, successfully in the end, that it was not bound by that easement agreement.

There are three important elements to the judgment. The first deals with policy - or rather the lack of a policy justification for the protection of private easements. One searches, it seems, in vain for a cogent reason for conferring a special protection on private easements. Indeed, such incorporeal rights seem like the very item which Torrens regarded as invidious hidden interests. Given the underlying rationale of land titles

For ease of reference, Land Titles Act, R.S.A. 1980, c. L-5, s. 65(1) provides:

"The land mentioned in any certificate of title granted under this Act is, by implication and without any special mention therein, subject to

(a) any subsisting reservations or exceptions, including royalties, contained in the original grant of the land from the Crown.

(b) all unpaid taxes, including irrigation and drainage district rates,

(c) any public highway or right of way or other public easement, howsoever created, on, over or in respect of the land,

(d) any subsisting lease or agreement for a lease for a period not exceeding 3 years, if there is actual occupation of the land under the lease or agreement,

(e) any decrees, orders or executions, against or affecting the interest of the owner of the land, that have been registered and maintained in force against the owner,

(f) any right of expropriation that may by statute be vested in any person or corporation or Her Majesty, and

(g) any right of way or other easement granted or acquired under any Act or law in force in Alberta." 
registration, and in the absence of a strong countervailing policy, a strict construction of the scope of all overriding interest provisions is appropriate. That is the posture adopted in the Court of Appeal. ${ }^{4}$

A second facet of the decision concerns the effect of prior case law on this subject. The language employed in the Alberta statute is sufficiently idiosyncratic that a reluctance to adopt interpretations followed in other jurisdictions, based on different formulations, appears warranted. It would be another matter altogether if one could glean a convincing policy analysis from those earlier authorities. In Alberta, before Petro-Canada, there was no appellate decision dealing squarely with this issue, a fact which the panel itself regarded as remarkable. ${ }^{5}$ It is rather extraordinary, given that in 1989 , in the case of Husky Oil v. Shelf Holdings, ${ }^{6}$ the Court of Appeal had before it facts which would have allowed the question to be treated. However, the Court in Shelf proceeded on the assumption that the matter was not in dispute $^{7}$ and so in Petro-Canada the status of easements as overriding interests was broached as if it were an issue of first impression. ${ }^{8}$

Thirdly, one must have regard to the language of the Act which, because of its curious wording, invites some semantic wrangling. While the Land Titles Act ostensibly allows for some easements as overriding interests, the ambit of the exception was said to exclude private easements granted by express contract, which are not created by "statute" or "law", as those terms are used in the statute. The reference to "law" was taken not to refer to the general common law of contract. Easements which are protected as overriding interests were thought to include, for example, easements of necessity, and the right of entry implied at common law in favour of a person acquiring mines and mineral rights.' Moreover, under another provision, public easements "howsoever created" are protected, leaving the implication that a more narrow class of private easements was contemplated as overriding interests.

\section{COMMENTARY}

At its core, the ruling in Petro-Canada seems correct and, if anything, is somewhat tentative, for the stated ratio is narrow: it was held that, at the very least, an express agreement for a private easement (where made without reference to any statutory power

4.

See also E. Mirth, Annot.: Husky Oil Operations Ltd. v. Shelf Holdings Lid. (1989), 65 Alta. L.R. (2d) 300 (C.A.).

\section{Supra, note 3 at 2 .}

(1989), 65 Alta. L.R. (2d) 300 (C.A.). The analysis in the case centred on whether a pipeline easement violated the requirement that an easement be non-possessory in nature. For a comment on this aspect, see B. Ziff and M.M. Litman, "Easements and Possession: An Elusive Limitation", [1989] Conv. 296.

Ibid. at 307.

Another decision, Card v. Transalta Utilities Corporation (1987), 57 Alta L.R. (2d) 155 (Q.B.), which dealt with the same issue considered in Shelf, may also be seen as accepting (or assuming) that private easements are overriding interests. In Petro-Canada, supra, note 3 at 6 the Court of Appeal was prepared to overrule Card to the extent that it contradicted the holding in the instant case. For a suggestion that the easements in both Card and Shelf were created, in some sense, under the Pipeline Act, R.S.A, 1980, c. P-8, see Petro-Canada, supra, note 3 at 5. 
to impose an easement) is not an overriding interest. The same must be true not only for agreements for easements, but also properly executed (but unregistered) easement conveyances.

Additionally, even if it had been held that easements remained en dehors the Land Titles Act, it might not necessarily follow that Shaganappi would have been held to be bound. After all, an agreement for an easement must create no more than an equitable entitlement. If so, it would not be binding on a person whom equity regards as a bona fide purchaser for value without notice; presumably Shaganappi could have claimed this status. It would be bizarre if, somehow, the equitable doctrine of notice was held to be inapplicable to overriding interests.

The Court of Appeal's interpretation of the Alberta provision that express easements are not created by "law" appears at first to be illogical. ${ }^{10}$ Fundamentally, property and law are inseparable concepts, for there can be no property without law. In Bentham's words, "[t]ill law existed, property could scarcely be said to exist. Property and law are born together and die together"." However, were this a guiding principle in the drafting of the easement provision, the use of both "statute" together with "law" would be redundant; perhaps neither is necessary.

The decision in Petro-Canada does not endeavour to resolve the mystery as to why private easements were included as overriding interests in the first place. This issue is not unique to Alberta; the exception has surfaced in a number of jurisdictions. For example, in Manitoba, private easements "howsoever created"12 are exempt from the need to register; in Ontario a broad protection also exists. ${ }^{13}$ A special treatment of easements can be traced back almost as far as the first Torrens statute. That Act came into force in July, $1858,{ }^{14}$ and extensive amending legislation was introduced and enacted later that same year. Among the changes was section 20, which provided as follows:

Notwithstanding any error or omission in the observance of any formality herein prescribed to be observed in bringing land under the operation of this Act, and excepting in the case of frauds, and so far as regards any wrong description of any land, or of its boundaries, or the omission or misdescription of any right-of-way or other easement, created in, or existing upon, any land under the operation of this Act, every certificate of title ... shall absolutely vest the estate or interest in the land therein mentioned, in the manner and to the effect expressed in such certificate of title or entry ... ${ }^{15}$

This wording leaves some doubt (at least in my mind) as to whether or not easements were meant to be covered by the general requirements of registration. Whatever confusion this might have generated, the changes which came into force in 1860 less

The Court acknowledged that the law of contract (out of which express grants arise) forms part of the common law: ibid. at 3 .

J. Bentham, The Limits of Jurisprudence Defined (New York: Columbia, 1945) at 85.

Real Property Act, R.S.M. 1988, c. R3O, s. 58(1)(c).

Land Titles Act, R.S.0. 1980, c. 230, s. 47(1), para.2.

Real Property Act (South Australia), 21 Vict. No. 15. No special provisions existed for easements.

Real Property Law Amendment Act (South Australia), 22 Vict. 16. 
ambiguously provided that title was subject to "the omission or misdescription or any right of way or other easement". ${ }^{16}$ This phrase has been taken to refer only to those easements omitted by error of the registrar, ${ }^{17}$ or those which existed before land was brought under the Torrens system. ${ }^{18}$

The exception contained in the federal Northwest Territories Real Property Act of 1886 may have been geared towards that latter approach. That Act protected "any subsisting right of way or other easement, howsoever created ..."..$^{19}$ In short order, there were several amendments to that provision. In 1894, private easements were removed altogether as overriding interests, ${ }^{20}$ but four years later, there was a reinstatement for "any right or other easement granted or acquired under the provisions of The North-west Irrigation Act". ${ }^{21}$ That was how the matter stood under the federal legislation in $1906 .{ }^{22}$ In that year, the Alberta statute which forms the core of the current law was passed and the special status granted to irrigation easements under the federal law was extended. The phrase found in the 1906 Alberta Act is substantially the same as that now in force. ${ }^{23}$ Beyond this, the trail is cold.

Despite the absence of a convincing justification, the Court of Appeal has nevertheless adopted a reading of the Alberta law which leaves room for some easements to remain as overriding interests. If the specific examples mentioned in the case are a guide, ${ }^{24}$ this restricted class may be described generically as comprising those easements implied by a grant or reservation. Included are: (i) intended easements; (ii) those arising out of necessity; and (iii) easements which crystallize by virtue of the rule in Wheeldon v. Burrows. $^{25}$ Again, superficially, it seems wrong to regard any of these as being created by law any more than had they been contained in an express grant. Certainly none of these arise by operation of law alone, for all turn on the inferred intentions of the parties to the initial transaction. Even the easement of necessity is properly described in this way. To borrow from a clever wag, intention is the mother of necessity. ${ }^{26}$ In other

Real Property Act, 1860, 23 \& 23 Vict. No. 11, s. 41. See further W.N. Harrison, "The Transformation of Torrens's System into the Torrens System" (1964), 4 U.Q.L.J 125.

Christopoulos et al. v. Kells (1988), 13 N.S.W.L.R. 54 I (C.A.); Papadopoulos v. Goodwin. [1983] 2 N.S.W.L.R. 113. See especially Auerbach v. Beck (1985), 6 N.S.W.L.R. 424; but cf. Kebewar Pty Lid. v. Harkin (1987), 9 N.S.W.L.R. 738 (C.A.).

Sutton v. O'Kane [1973] 2 N.Z.L.R. 304 (C.A.); see also Jobson v. Nankervis (1943), 44 S.R. (N.S.W.) 277.

The Territories Real Property Act, S.C. 1886, c. 26, s. 61(c) (emphasis added).

Land Titles Act, S.C. 1894, c. 28 (see s. 56).

An Act to Further Amend the Land Titles Act, S.C. 1898, c. 32, s. 8.

Land Titles Act, R.S.C. 1906, c. 110, s. 73(g). There was a consequential change, the word "North-west" having been removed.

Land Titles Act, S.A. 1906, c. 24, s.43(g). For completeness, the wording there was "[a]ny right of way or other easement granted or acquired under the provisions of any Act or law in force in the Province".

See text accompanying note 9, supra.

As to the general nature of these implied interests, see K.J. Gray, Elements of Land Law (London: Butterworths, 1987), at 668ff.

L. Crabb. "Necessity: the Mother of Intention", [1981] Conv. 442. This view has not been universally held. The idea that easements of necessity are creatures of public policy may have influenced the drafting of the Alberta provision. 
words, easements arise from necessity only because it is assumed to be necessary to the parties. They do all arise, however, because the law will write in such terms to give effect to the unarticulated intentions of the parties and in that way they differ from interests which are expressly created. Likewise, easements arising from prescription are fictionalized as arising from a prior grant. ${ }^{27}$

Does it make any sense to confer upon implied easements a special status under the land registration rules? Since implied easements arise without the parties having directed their minds to the issue, it is unlikely that the recipient-party would then proceed to register. Perhaps the land titles exception serves to protect against this form of excusable oversight. ${ }^{28}$ However, even if this is right, it is easily counterbalanced by the general justification for the mirror principle. Allowing implied easements as overriding interests makes it especially difficult for purchasers to acquire land confident that they have a complete catalogue of all interests. Since easements are incorporeal hereditaments, there will not necessarily be any physical evidence that one exists over a given tract of land. Additionally, while there may exist a registered transfer out of which the easement was implied, it will be registered on the title to the dominant, not the servient, tenement. In other words, given the nature of implied easements, this is just the type of interest which one would wish to require to be placed on the register. Precisely how the holder would note such an interest on title, and define it accurately, is another matter. ${ }^{29}$

In a recently published report, the Joint Land Titles Committee concluded that easements were not entitled to special protection, and therefore would not, under their proposed land titles reform, be regarded as overriding interests. ${ }^{30}$ This accords with the Court of Appeal's reasoning. The Court did not provide a policy reason to fortify the contention that implied easements should remain protected. However, unless the Court of Appeal had adopted a wholly cavalier attitude towards the judicial law-making role, it could only constrict the ambit of the statutory exception (as it did) and not eviscerate it entirely. Otherwise it might have been minded to draw a blue pencil line through the full provision.

27. Of course, such easements cannot arise in Alberta: Limitation of Actions Act, R.S.A. 1980, c. L-15, s. 50.

28. In Queensland it has been held that easements of necessity are outside of the Torrens system, and are binding on bona fide purchasers for value without notice: Price v. McGuinness, [1966] Qd. 591 (S.C.).

29. See further Australian Hi-Fi Publications Pty Ltd. v. Gehl, [1979] 2 N.S.W.L.R. 618 at 623 (C.A.).

30. Joint Land Titles Committee, Renovating the Foundation: Proposals for a Model Land Recording and Registration Act for the Provinces and Territories of Canada (1990), at 27. 